\title{
EKSISTENSI HIMPUNAN LANSIA SAYANG BUNDA DI SULAWESI SELATAN
}

\author{
Oleh: Muliaty Amin \\ Guru Besar Fakultas Dakwah dan Komunikasi \\ UIN Alauddin Makassar
}

\begin{abstract}
:
The existence of the Elderly Association in South Sulawesi is an organization that concentrates on empowering aumlansia, as a forum for the elderly to stay in touch and contribute to advance South Sulawesi. The research method used is field research, prioritizing da'wah based on the image of Da'i based on research and using science of dakwah communication that synergize with multi disciplinary approach. The implication of this research is the urgency to empower the elderly who are incorporated in the organization of the Association of Elderly Mother of South Sulawesi, whose mission is to empower the elderly. For that, in the future strived to realize the mission of jama'ah for the elderly for empowerment evenly.
\end{abstract}

\section{Keyword: \\ Existence, elderly, Mother}

\section{PENDAHULUAN}

Menjadi orang tua lanjutusia (Lansia) acap kali distereotipkan sebagai orang-orang yang sudah tidak mampu melakukan hal-hal yang produktif atau bahkan lebih buruk lagi dianggap sebagai burden senior citizens (masyarakat yang menjadi beban keluarga). Hal ini terindikasi dengan makin banyaknya jumlah penghuni panti jompo dari tahun ketahun akibat berbagai alasan. ${ }^{1}$ Keadaan seperti ini akan diperparah lagi jika para lansia ini tidak dilatih untuk mampu produktif di masa tua mereka di tempat panti jompo ini. Dengan begitu konsekuensinya adalah mereka seutuhnya akan menjadi beban masyarakat dan Negara. ${ }^{2}$ Kurangnya produktivitas lansia diakibatkan adanya penyakit degeneratif, yakni sebuah penyakit yang mengakibatkan berkurangnya fungsi sel tubuh menjadi leih buruk. Factor inilah yang menjadi penghambat bagimasyarakat lansia untuk berproduktivitas.

Masyarakat lanjut usia dapat dikategorikan menjadi dua, yakni lansia potensial dan lansia non-potensial. ${ }^{3}$ Lansia potensial adalah lansia yang masih mampu melakukan kegiatan/pekerjaan yang menghasilkan barang atau jasa. Sedangkan, lansia non-potensial adalah lansia yang tidak berdaya mencari nafkah sehingga hidupnya bergantung pada bantuan orang lain. Undang-undang Republik Indonesia Nomor 36 Tahun 2009 Pasal 38 ayat 1 menetapkan bahwa upaya pemeliharaan bagi lanjut usia (lansia) harus ditujukan untuk menjaga agar tetap hidup sehat dan produktif secara sosial maupun ekonomi sesuai dengan martabat kemanusiaan. Pasal 2 menetapkan pemerintah wajib menjamin ketersediaan fasilitas pelayanan kesehatan dan menfasilitasi kelompok lanjut usia untuk dapat tetap hidup mandiri dan produktif secara social dan ekonomis. 
Sejalan dengan program pemerintah, posisi dan strategi Himpunan Lansia SayangBunda di Sulawesi Selatan (sul-sel) hadir guna mendukung program pemerintah untuk meningkatkan kesejahteraan social masyarakat lansia yang berujung pada peningkatan Usia Harapan Hidup(UHH) dan masa produktif serta lebih mendekatkan diri kepada Tuhan Yang Maha Esa (YME).

\section{PEMBAHASAN}

\section{Pengertian Lansia}

Pengertian lansia sebagai singkatan dari lanjut usia, adalah periode disaat organisme seseorang telah mencapai kemasakan dalam ukuran dan fungsi yang telah menunjukan kemunduran sejalan waktu.

Ada beberapa pendapat mengenai usia kemunduran, ada yang menetapkan usia 60 tahun, 65 tahun dan 70 tahun. Badan kesesahatan dunia (WHO) menetapkan 65 tahun sebagai usia yang menunjukkan proses menua yang berlangsung secara nyata dan seseorang telah disebut lanjut usia. Dengan demikian, lansia merupakan periode penutupdalam rentang hidup seseorang. Masa ini dimulai dari umur enampuluh tahun sampai meninggal, yang ditandai dengan adanya peubahan yang bersifat fisik dan psikologis yang semakin menurun. Lansia dikelompokan dalam usia pada manusia yang telah memasuki tahapan akhir dari fase kehidupannya secara fisik.

Dapat dirumuskan bahwa lansia merupakan periode seorang individu yang telah mencapai kemasakan dalam proses kehidupan, serta telah menunjukkan kemunduran fungsi organ tubuh sejalan dengan waktu, tahapan ini berbeda-beda menurut para pakar, ada yang menyatakan mulai dari usia 55,60,65, namun penulis lebih mengikuti pendapat yang menjelaskan bahwa usia lansia ketika memasuki 60 tahun yang disertai berbagai gejala, terutama kemunduran faktor fisik dan faktor psikologis. Kemunduran dapat berdampak pada psikologis lansia. Motivasi memiliki peran yang penting dalam kemunduran pada lansia. Kemunduran pada lansia semakin cepat apabila memiliki motivasi yang rendah, sebaliknyanjika memiliki motivasi yang kuat maka kemunduran itu akan lama terjadi.

Lansia memiliki status dalam kelompok minoritas karena sebagai akibat dari sikap sosial yang tidak menyenangkan terhadap orang yang lanjut usia dan diperkuat oleh pendapatpendapat klise yang jelek terhadap lansia. Pendapat-pendapat klise itu seperti lansia lebih senang mempertahankan pendapatnya daripada mendengarkan pendapat orang lain. Dalam keadaan demikian memang dalam keadaan lansia dibutuhkan perubahan peran. Perubahan peran tersebut dilakukan karena lansia mulai mengalami kemunduran dalam segala hal. Perubahan peran pada lansia sebaiknyadilakukan atas dasar keinginan sendiri bukan atas dasar keinginan sendiri bukan atas dasar tekanan dari lingkungan.

Penyesuaian yang buruk pada lansia, terutama perlakuan yang buruk terhadap orang lanjut usia membuat lansia cenderung mengembangkan konsep diri yang buruk. Lansia lebih memperlihatkan bentuk perilaku yang buruk. Karena perlakuan yang buruk itu membuat penyesuaian diri lansia menjadi buruk. Namun demikian, berbagai karakteristik lansia yang 
bersifat positif seperti adanya keinginan untuk meninggalkan warisan, fungsi seseorang yang dituakan, kelekatan dengan objek-objek yang dikenal, perasaan tentang siklus kehidupan, tetap memiliki kriativitas, memiliki rasa ingin tahu dan kejutan (surprice), perasaan tentang penyempurnaan atau pemenuhan kehidupan, kontrol terhadap takdir. ${ }^{4}$

Berbagai karakteristik negatif maupun positif bagi lansia, menyebabkan orang menjadi tua sesungguhnya merupakan fenomena biologis, tetapi fungsi, kedudukan, peran sosial kelompok dalam keluarga dan komunitas adalah konstruksi budaya sebagai proses alami yang disertai adanya penurunan kondisi fisik, psikologis maupun sosial yang saling berinteraksi satu sama lain. Karena itu, tahap memasuki usia tua ini akan dialami oleh semua orang dan tidak mungkin bisa dihindari, tetapi kondisi fisik dan psikologis lansia sangat berbeda dari satu lansia dengan lansia yang lainnya. Kekuatan tubuh yang mulai berkurang, daya penyesuaian diri, reaksi terhadap lingkungan, daya inisiatif dan daya kreatif yang mulai menurun pada lansia dapat menimbulkan masalah psikologis.

Secara psikologis, lansia merupakan periode penutup dalam rentang hidup seseorang yang mana periode ini seseorang telah beranjak jauh dari periode sebelumnya yang lebih menyenangkan dan penuh dengan manfaat. Untuk itu terkadang muncul penyesalan dan rasa ingin mengulang kembali pada periode sebelumnya. Sama dengan usia-usia yang sebelumnya yang ada dalam rentang kehidupan seseorang, usia ini juga ditandai dengan adanya perubahan fisik dan psikologis tertentu. Karena hal itulah yang membedakan dan yang menentukan seseorang masuk pada periode tertentu. Pada usia lansia ini ciri-ciri yang ada cenderung menuju dan membawa kepada penyesuaian diri buruk dari yang baik. ${ }^{5}$ Oleh sebab itulah usia ini cukup ditakuti oleh setiap orang dari pada usia yang sebelumnya. Berikut ini beberapa ciriciri pada usia lansia sebagai kelanjutan penjelasan pengertian lansia yang telah dikemukakan.

\section{Merupakan Periode Kemunduran}

Setiap orang pasti mengalami perubahan yang bersifat avaluatif artinya setiap orang pasti mengalami perubahan yang membawa pada kedewasaan dan keberfungsian. Akan tetapi apabila telah memasuki usia lansia perubahan yang terjadi tidak lagi bersifat evaluatif lagi sebab sesuai dengan hukum kodrat manusia yang pada umumnya yang biasa disebut dengan menua. Penuaan inilah yang menyebabkan menurunnya fisik, mental dan keberfungsiannya juga. Kemunduran fisik dan mental akan terjadi secra perlahan dan bertahap, penurunan ini biasa disebut dengan senescence, yakni masa proses menjadi tua. ${ }^{6}$ Dengan demikian seseorang yang berada atau memasuki usia ini ia memiliki sifat yang kurang perhatian, keterasingan, dan eksentrik sehingga penyesuaian dirinya pun semakin buruk. Penurunan fungsi fisik dan mental ini terjadi tatkala seseorang telah memasuki usia 60 tahun atau mungkin tidak terjadi sama sekali sebab orang tersebut meninggal sebelum memasuki usia pemunduran.

Kemunduran fisik dan mental seseorang terjadi salah satunya disebabkan oleh semakin menuanya sel-sel yang ada dalam tubuh orang tersebut. Kemunduran juga akan berdampak pada psikologi seseorang, dampak tersebut dapat berupa sifat tidak senang pada diri sendiri, 
orang lain, pekerjaan dan keadaan lainnya. Apabila seseorang mampu mengatasi ketegangan dan sters yang dalam kehidupannya maka akan sangat berpengaruh pada laju kemunduran dirinya.

\section{Perbedaan Individual pada Efek Menua}

Seseorang akan memasuki usia lanjut, lansia dengan tipikal atau ciri yang berbeda sebab setiap orang memiliki perbedaan pada sifat bawaan, sosial ekonomi, latar belakang pendidikan, dan pola hidupnya yang lebih utama lagi yakni perbedaan jenis kelamin seseorang. ${ }^{7}$ Penuaan fisik akan terjadi lebih cepat dibandingkan dengan dengan penuaan mentalnya tetapi terkadang juga dapat terjadi sebaliknya sebab orang tersebut banyak memikirkan proses penuaannya dan membiarkan saja mentalnya mengalami penuaan.

3. PenyesuaianDiri yang Buruk

Orang yang berada pada usia ini. Lansia sering kali bersifat tidak menyenangkan atau cenderung bersikap buruk, ini disebabkan karena adanya perasaan tidak menyenangkan yang ditimbulkan oleh orang-orang yang ada di sekitar mereka dalam memperlakukan mereka. Karena adanya sikap tersebut berakibat pada sulitnya mereka melakukan adaptasi dibingkan dengan mereka dimasa muda. Hal ini juga dapat disebabkan oleh semakin hilangnya status mereka dalam kegiatansosial atau pekerjaan.

\section{Adanya Keinginan untukMenjadi Muda Kembali}

Status minoritas (keterasingan sosial) yang dialami oleh para lansia menyebabkan munculnya keinginan untuk kembali menjadi muda, sehingga pada usia ini sering kali kita temukan akan adanya beberapa lansia yang menggunakan obat baik tradisional maupun kimia untuk membuat mereka tetap awet muda. Padahal obat-obatan yang digunakan juga dapat mengakibatkan kerusakan sel dalam tubuh atau dapat memunculkan penyakit yang tidak diinginkan. Selain itu bagaimanapun seseorangberusaha menjadi muda kembali tidaklah mungkin terlaksana sebab itu sudah merupakan hukum alam yang pasti dilalui oleh seseorang.

\section{Perkembangan Fisik Lansia}

Pada usia ini kondisi tubuh seseorang pasti akan berangsur-angsur melemah. Antara oranag yang satu dengan yang lain kemunduran fisik akan berbeda-beda sebab adanya variasi pada proses dan kecepatan kerusakan. Berikut perubahan yang akan terjadi pada fisik yang dialami para lansia, seperti perubahan penampilan, perubahan bagian tubuh, perubahan pada fisiologis, perbahan panca indera, dan perubahan seksual. ${ }^{8}$

a) Perubahan Penampilan

Banyak disebutkan bahwa perubahan fisik yang paling terlihat adalah perubahan pada wajah meski sudah berusaha menutupinya namun selalu ada saja aspek yang tidak dapat ditutupi ketika seseorang itu berada pada usia lansia. Selain wajah yang terlihat juga adalah tangan yang merupakan bagian tubuh yang tidak dapat ditutupi. Perubahan yang ada tidaklah terjadi secara serempak akan tetapi lambat laum perubahan tersebut pasti akan nampak. 
b) Perubahan Bagian Tubuh

Baik bagian luar maupun bagian dalam tubuh semua pasti mengalami perubahan misalnya adanya pengapuran pada tulang, berkurangnya volume otak, perubahan isi perut, posisi jantung lebih dekat dengan dada tengah, usu yang melebar dan selainnya.

c) Perubahan pada Fisiologis

Selain perubahan bagian tubuh, organ-organ dalam tubuh pun mengalami perubahan (penurunan) fungsi seperti pengaturan temperatur tubuh yang diakibatkan penurunan fungsi organ.

d) Perubahan pada Panca Indra

Pada usia ini panca indra mengalami penurunan sensivitas dan efisiensinya dibandingkan dengan fungsinya diwaktu muda misalnya saja mata yang sudah mulai rabun, telinga yang kurang busa menerima suara yang lemah.

e) Perubahan Seksual

Pada usia ini sistem reproduksi seseorang sudah mengalami banyak perubahan.oleh karena itu pada usia ini pada umumnya terjadi penurunan potensi seksual. Perubahan juga terjadi pada ciri-ciri seks sekunder seperti perubahan suara, titik nada tinggi, rambut, otot yang mulai melembek.

6. Perubahan Kemampuan Motorik Lansia

Terjadi penurunan kekuatan yang terlihat pada mengendornya otot-otot yang ada pada beberapa bagian tubuh. Para lansia cenderung lebih cepat cakei dan perlu waktu yang lama untuk memulihkannya kembali. Penurunan pada kecepatan gerakpun juga terjadi ini terlihat dari banyaknya waktu yang dibutuhkan untuk menanggapi suatu hal, dan akan semakin menurun pada usia diatas 60 tahun. Pada usia ini para lansia akan lambat dalam mempelajari suatu hal yang baru sehingga hasil hasil dari belajar itupun cenderung kurang memuaskan. Orang lanjut usia cenderung canggung, kagok, dan kaku sehingga sering kali kita temukan mereka menjatuhkan barang yang mereka pegang. Ini terjadi disebabkan akan adanya kerusakan pada sistem motorik mereka yang sudah menua.

\section{Perkembangan Mental (Intelektual)}

Kerusakan atau penurunan mental akan berjalan vertikal bersama dengan adanya penurunan dan kerusakan fisik seseorang. Salah satu yang menyebabkan yang menunjang terjadinya kerusakan mental seperti terjadinya penurunan fungsi alat indra, hormon, dan lainlain. Selain dari diri lansia itu sendiri yang turut mempengaruhi mental adalah lingkungan. Pada orang yang melakukan latihan atau pekerjaan yang membutuhkan kemampuan intelektual penurunan atau perubahan mental akan lebih lambat dibanding dengan orangorang yang menganggur.

Pada usia ini seseorang akan membutuhkan banyak waktu dalam mempelajari hal-hal yang baru dan hasilnya pun tidak sebagus orang usia muda. Terjadi penurunan kemampuan dalam menyimpulkan diakibatkan oleh sikap yang terlalu berhati-hati. Kemampuan untuk berfikir bagi para lansia cenderung berkurang sebab terjadinya kapasitas atau keinginan maju. 
Daya ingat yang dimiliki oleh para lansia juga mengalami penurunan maka tidak heran jika mereka seringkali lupa akan suatu hal, selain itu mereka mengalami kesusahan dalam mengingat hal-hal yang baru di sekitar mereka. Pada usia ini juga terjadi penurunan rasa humor atau tidak tertarik pada hal-hal yang lucu.

8. Minat-minat pada Usia Lansia

Tidak hanya fisik dan mental saja yang mengalami perubahan tetapi perubahan tersebut juga terjadi pada kecenderungan atau minat yang mereka miliki. Diantara minat atau keinginan yang ada pada usia ini sebagai berikut:

a. Minat pada diri sendiri, semakin tua seseorang maka ia akan semakin dikuasai oleh diri sendiri sehingga ia cenderung bersikap egois dimana ia lebih memikirkan dirinya sendiri dibanding orang lain.

b. Minat pada penampilan dan pakaian, meski pada beberapa orang tidak memperhatika atau bersikap acuh pada penampilan tapi ada beberapa orang yang sangat memperhatikan penampilannya. Ada beberapa sebab sehingga seseorang bersikap demikian diantaranya status sosial, status ekonomi, dan tempat tinggal.

c. Minat pada uang, pada umumnya minat pada uang semakin berkurang sebab semakin besarnya kesadaran tentang itu. Tapi bagi pengangguran dan pensiunan malah merangsang mereka untuk berusaha keras demi memenuhi kebutuhan mereka.

Selain itu, ada pula minat rekreasi. Minat ini cenderung meski demikian mereka tetap butuh rekreasi dan hiburan untuk itu beberepa diantara mereka ada yang membaca, menulis surat, mendengarkan radio, menonton TV, berkunjung kerumah teman atau sanak saudara, dan lain-lain sebagainya, sebagai bentuk hiburan dan rekreasi mereka. Ada beberapa kondisi yang memengaruhi perubahan minat rekreasi ini diantaranya: kesehatan, status ekonomi, pendidikan, status pernikahan, jenis kelamin, kondisi kehidupan.

Ditemukan pula adanya minat sosial, karena mereka merasa terasingkan sebab banyak berkurangnya aktivitas sosial yang mereka lakukan. Selain itu yang turut mempengaruhi ialah sikap mereka yang lebih egois dibanding periode sebelumnya.

\section{Lansia PerspektifYuridis Formal}

Pedoman penyelenggaraan pembinaan lansia secara yuridis formal telah diatur dalam peraturan pemerintah. Hal ini dipahami sejak ditetapkannya peraturan Pemerintah Republik Indonesia nomor 5 tahun 1958, tentang penyerahan tugas Bimbingan dan Perbaikan Sosial kepada Daerah Tingkat Kebimbingan Sosial. Daerah tingkat ke-1, selanjutnya ditetapkan Undang-undang Nomor 6 tahun 1974 tentang Ketentuan-ketentuan pokok kesejahteraan sosial (lembaran negara tahun 1974 Nomor 53, tambahan lembaran negara nomor 3039), dan Undan-undang nomor 4 tahun 1979 tentang kesejahteraan (lembaran negara tahun1979 nomor 32, tambahan lembaran negara nomor 3143). Peraturan pemerintah tersebut ditetapkan dalam 
upaya pengasuhan danpembimbingan masyarakat, termasuk untuk lansia yang semakin meningkat jumlahnya secara kuantitas.

\section{Deskripsi Lokasi dan Obyek Penelitian}

Penelitian ini mengambil obyek pada himpunan lansia Sayang Bunda Sulawesi Selatan, yang berkedudukan di kotaMakassar sebagai ibu kota provinsi Sulawesi Selatan, merupakan pintu gerbang dan pusat perdagangan kawasan Timur Indonesia. Secara administratif kota Makassar terletak pada titik koordinat $119^{0}, 24^{0}, 17^{0}, 38^{0}$, bujur timur dan $5^{0}, 8^{0}, 6^{0}, 19^{0}$, lintang selatan.

Wilayah kota Makassar bila dilihat dari segi pemerintahannya terletek di daerah pantai, memanjang pada bagian Barat dan Utara kota, yang merupakan salah satu Kota yang mempunyai peluang untuk pengembangan pengolahan hasil usaha penangkapan ikan laut, pemeliharaan ikan tambak dan penggaraman. Selain itu, Kota Makassar ini merupakan pusat perdagangan hasil perikanan, terutama dari daerah Pangkep, Maros, Gowa, dan Takalar.

Kota Makassar berbatasan dengan daerah-daearah lain atau kabupaten sekitar, yakni sebelah Selatan berbatasan dengan Kabupaten Gowa. Sebelah Utara berbatasan dengan Kabupaten Pangkep. Sebelah Timur berbatasan dengan Kabupaten Maros. Sebelah Barat berbatasan dengan Selat Makassar.

Kota Makassar telah mengalami pemekaran dari 11 kecamatan menjadi 14 kecamatan, dengan luas wilayahnya secara keseluruhan 175, $77 \mathrm{KM}^{2}$. Adapun luas wilayah perkecamatan-kecamatan Kota Makassar, dapat dilihat dalam tabel berikut:

Tabel

Luas Wilayah Perkecamatan di Kota Makassar

\begin{tabular}{|c|c|c|}
\hline No & Kecamatan & Luas Wilayah $\left(\mathrm{KM}^{2}\right)$ \\
\hline 1 & Rappocini & 5,94 \\
\hline 2 & Tamalate & 5,83 \\
\hline 3 & Makassar & 2,1 \\
\hline 4 & Mariso & 1,99 \\
\hline 5 & Mamajang & 2,63 \\
\hline 6 & Ujungpandang & 2,52 \\
\hline 7 & Tallo & 2,25 \\
\hline 8 & Manggala & 1,82 \\
\hline 9 & Pannakukang & 9,23 \\
\hline 10 & Wajo & 20,21 \\
\hline 11 & Bontoala & 17,05 \\
\hline 12 & Ujung Tanah & 24,14 \\
\hline 13 & Tamalanrea & 48,22 \\
\hline 14 & Biringkanaya & 31,84 \\
\hline & Jumlah & 175,77 \\
\hline
\end{tabular}

Sumber Data: BPS Kota Makassar, tahun 2014 
Berdasarkan pada tabel di atas, maka dapat di ketahui bahwa yang paling luas wilayahnya adalah Kecamatan Tamalanrea, yakni seluas 48,22 $\mathrm{KM}^{2}$. Sedangkan yang paling sempit atau kecil wilayahnya adalah Kecamatan Manggala, yakni 1,8 $\mathrm{KM}^{2}$. Sebelumnya, dua wilayah yang disebutkan ini, yakni yang terluas dan yang tersempit atau yang terkecil adalah wilayah adalah hasil pemekaran.

Selanjutnya tentang keadaan geografis Kota Makassar dapat diketahui dengan melihat keadaan iklimnya tropis, karena letaknya menghampiri garis tengah bumi yang dikenal dengan garis khatulistiwa dengan kelembaban $56-85 \%$, curah hujan rata-rata $171 \mathrm{~mm}$, dengan jumlah hari berkisar 171 hari pertahun, suhu rata-rata $27^{\circ} \mathrm{c}-33^{\circ} \mathrm{c}$ dan kecepatan angin $2-3$ knot perjam.

Pada daerah daratan rendah mulai dari tepi pantai sebelah barat melebar ke arah timur sejauh kurang lebih 20 kilometer dan memanjang dari selatan ke utara, merupakan daerahdaerah pengembangen pemukiman, pertokoan, perkotaan, pendidikan. Di bagian utara bahkan terdapat kawasan industri yang boleh dikatakan sudah mengalami perkembangan pesat.

Kota Makassarmempunyai posisi yang strategis, keadaan wilayah datar dan hanya sebagian kecil dataran tinggi yang terdapat di kecamatan Biringkanaya. Secara keseluruhan ketingian di permukaan laut berkisar antara 1-25 meter dengan kemiringan tanah antara 0-5 derajat ke arah barat.

Di Kota Makassar terbentang dua buah sungai, yaitu sungai Jeneberang dan sungai Tallo. Sungai jeneberang bermuara di bagian selatan kota dan melintasi Kabupaten Gowa, sedangkan sungai Tallo bermuara di bagian utara kota.

\section{Profil Himpunan Lansia Sayang Bunda di Sulawesi Selatan}

Himpunan lansia Sayang Bunda Sulawesi Selatan adalah sebuah organisasi yang didirikan pada tanggal 19 juni 2009 di hotel Marannu Makassar. Visi organisasi ini, adalah untuk tidak menjadikan lansia sebagai beban bagi orang lain. Artinya adalah melalui himpunan ini diharapkan pada lansia dapat bermanfaat terhadapa orang lain khususnya mereka para lansi.

Apa yang dilakukan oleh Hj. Ince Ratna Nurhayati Yasin Limpo denganmendirikan

Himpunan Lansia Sayang Bunda Sulawesi Selatan ini, adalah sebuah bentuk dorogan individual (pribadi) terhadap keprihatinan kepada kaum lansia khususnya di Sulawesi Selatan.

Himpunan Himpunan Lansia Sayang Bunda Sulawesi Selatan sebagai sebuah organisasi dimaksudkan guna memudahkan mengorganisir tugas-tugas individu secara sistematik dibandingkan dengan hanya suatu perkumpulan masyarakat. Max Weber mendefinisikan organisasi sebagai "A system of purposeful, interpersonal activity designed to cordinate individual task" (sebuah sistem aktifitas/kegiatan interpersonal yang didesain dengan tujuan untuk mengkordinasi tugas-tugas individu). Artinya adalah Himpunan yang didesain oleh $\mathrm{Hj}$. Ince Ratna Nurhayati yasin Limpo ini memiliki tujuan berupa pemberdayaan lansia yang terorganisir dalam sebuah sistem kerja. 
Latar belakang berdirinya Himpunan Lansia Sayang Bunda Sulawesi Selatan, bermula dari percakapan para pendiri utamanya $\mathrm{Hj}$. Ince Ratna Nurhayati Yasin Limpi bersama koleganya yang ikut berpartisipasi dalam pendirian organisasi ini, mereka adalah Nurtiah Panawang, Andi wallang Bintang, $\mathrm{Hj}$. Isye Amu Madonza dan $\mathrm{Hj}$. Hadmijah Usman, yang semasa-masa aktif di legislative, terlintas dalam fikiran merekatentang kira-kira apa wadah yang dapat melanjutkan kebersamaa mereka yang telah terbangun, dan yang dapat bermanfaat bagi masyarakat. Maka berfikirlah untuk membentuk wadah berhimpun bagi Lansia di Sulawesi Selatan dengan sebutan Lansia Sayang Bunda Sulawesi Selatan. ${ }^{10}$ Dari hasil pemikiran itulah maka dilanjutkan didalam beberapa kali pertemuan informal untuk melegalkan organisasi tersebut.

Melalui sebuah pertemuan, sebagai tindak lanjut percakapan awal yang telah dimulai sebelumnya, tercetuslah ide untuk mendirikan sebuah klinik. Melalui upaya swadaya para pendiri dan dukungannya berbagai pihak berdirilah klinik yang diberi nama "Klinik Sayang Bunda". Selanjutnya beberapa waktu kemudian dibentuk koprasi dengan nama "Koprasi Sayang Bunda" yang telah berbadan hukum. ${ }^{11}$

Seiring berjalannya waktu, berbagai kegiatan dilaksanakan oleh klinik Sayang Bunda, seperti Senam Lansia secara rutin dilaksanakan dua kali dalam sebulan pada setiap sabtu pagi. Selain senam lansia dilaksanakan kegiatan ceramah agama yang temanya berkaitan dengan kesejahtraan lansia, seperti tentang kesehatan Lansia, dan urgensi terhadap kebutuhan spiritual terhadap lansia. ${ }^{12}$ Setelah melaksanakan berbagai kegiatan, maka selanjutnya dibentuk struktur pengurus dengan komposisi sebagai berikut:

\section{A. Susunan Nama-Nama PengurusHimpunan Lansia Sayang Bunda Sulawesi}

\section{Selatan}

\begin{tabular}{|c|c|}
\hline Pendiri / ketua & : Hj. Ince Ratna Nurhayati Yasin Limpo \\
\hline Wakil ketua & : Hj. A. Nurtiah Panawan, M.Si. \\
\hline Wakil ketua & : Hj. A. Wallang Bintang \\
\hline Sekretaris & : Hj. Hsdijsh Usman \\
\hline \multicolumn{2}{|c|}{ Wakil sekretraris : Agustiawati, S.Kep., NS. } \\
\hline \multirow[t]{3}{*}{ Sie. Organisasi } & : Hj. A. Ratna Tajudddin \\
\hline & Hj. Isyeamu Madonza \\
\hline & Hj. Catherine., SKM, S. Kep. \\
\hline \multirow[t]{4}{*}{ Sie kesehatan } & : Dr. Hj. Nurachma, S.Kep \\
\hline & Dr. Hj. Machdaniar Muin \\
\hline & Dr. Hj. Rusmini Abdullah \\
\hline & Dr. Irdayati, S.Kep., NS \\
\hline
\end{tabular}


Pelantikan pengurus sekaligus menjadi momen penting pendirian Lansia secara resmi dilaksanakan tanggal 19 juni 2009 di hotel Marannu Makassar, dihadiri oleh pemerintah setempat, yakni Gubernur Sulawesi Selatan dan beberapa intansi, dinas terkait yang memberikan dukungan, yakni Dinas Sosial Provinsi Sulawesi Selatan, Dinas tenaga kerja dan transmigrasi Provinsi Sulawesi Selatan, Biro Kesra Setda Provinsi Sulawesi Selatan, Badan Perbedaan Masyarakat desa dan kelurahan Provinsi Sulawesi Selatan, dan Dinas Kesehatan Provinsi Sulawesi Selatan.

Organisasi Himpunan Lansia Sayang Bunda yang diketua oleh ibu Gubernur Sulawesi Selatan, Ince Ratna Nurhayati Yasin Limpo tersebut, menjadi wadah bagi para lansia untuk saling bersilaturahmi sekaligus berkontribusi dalam memajukan Sulawesi Selatan.

Ince Ratna Yasin Limpo, melalui wawancara secara runtut menyatakan bahwa,Masa lansia, lanjut usia bagi seoang manusia bukan sesuatu hal yang perlu ditakuti, bahkan harus menjadi sebuah anugrah karena tidak semua orang diberikan kesempatan yang sama untuk hidup, panjang umur dan merasakan masa lansia itu. Menurutnya, salah satu persoalan yang sering terjadi yaitu karena mereka yang memsuki masa lansia dianggap akan menjadi beban bagi keluarganya, padahal apabila dipersiapkan dengan baik maka akan berjalan dengan bahagiakarena mereka masih bisa berkontribusi melalui saran dan kritiknya, karena itu adanya Himpunan Lansia Sayang Bunda dijadikan sebagai wadah untuk mensejahterakan lansia yang semakin banyak jumlahnya, yakni pada tahun 2002 lalu ada sekitar 400 juta penduduk Lansia di dunia termasuk di Indonesia, dan diperkirakan pada tahun 2050 mencapai 1,6 milyar orang. Dengan kehadiran Organisasi Himpunan Lansia Sayang Bunda ini, juga menjadi wadah atau tempat saling bersilaturahmi para lansia, sekaligus tentunya berkontribusi untuk kemajuan Bangsa dan Negara, khususnya di Sulawesi Selatan. ${ }^{13}$

Berdasarkan hasil wawancara tersebut, dipahami bahwa saat seseorang memasuki masa Lansia, maka tidak boleh dianggap tidak bisa melakukan apa-apa karena bisa saja para Lansia dulunya adalah seorang pejabat tertentu yang masih diharapkan bisa memberikan masukannya, masih bisa berkontribusi melalui saran dan kritiknya, sehingga kehadiran Lansia tetap memiliki peran terhadap pembangunan bangsa. Mereka mendapakan kesempatan yang sama untuk hidup, panjang umur dan merasakan masa lansia diharapkan tidak menjadi beban bagi keluarganya. Untuk itu maka lansia yang semakin bertambah, dan diperkirakan mencapai jumlah 1,6 milyar pada tahun 2050 senantiasa diharapkan memiliki adil bagi dirinya dan masyarakat, bangsa dan negara serta agama tentunya sehingga kehadiran Himpunan Lansia Sayang Bunda memiliki peran yang sangat dignifikan.

Dalam kaitan itu, Hj. Hadijah Usman menyatakan bahwa,Perempuan sebagai pembangunan mempunyai potensi yang sangatnbesar dan beragam. Khusus dalam interen jumlah penduduk Sulawesi Selatan yang relatif lebih banyaknjenis kelamin perempuan, menjadi kekuata bagi sebuah perubahandimana kualitas perempuan menjadi kunci perubahan lingkungan strategis yang sangat dinamis di era globalisasi saat ini. Salah satu indikator keberhasilan pembangunan adalah semakin meningkatnya usia harapan hidup 
penduduk, menyebabkan jumlah penduduk lanjut usia terus meningkat dari tahun ke tahun, sehingga diharapkan agar Himpunan Lansia Sayang Bunda ini dapat menghasilkan rumusan strategis dalam rangkameningkatkan kualitas hidup lansia di Sulawesi Selatan. ${ }^{14}$

Berdasarkan hasil wawancara diatas, dipahami bahwa Himpunan Lansia Sayang Bunda Sulawesi Selatan, diharapkan memberi kontribusi dan peran penting dalam pemberdayaan perempuan terutama perempuan lansia di Sulawesi Selatan sebagai provinsi terbesar keempat terbesar jumlah lansianya di luar pulau jawa. Data BPS menunjukkan jumlah lansia perempuan lebih banyak dari lansia laki-laki. Pertumbuhan penduduk lansia yang demikian cepat disertai kondisi jaminan sosial yang masi terbatas tingkat pendidikan dan kesejahteraan yang relatif rendah juga telah meningkatkan rasio ketergantungan yang cukup tinggi. ${ }^{15}$ Oleh karena itu kondisi seperti ini akan mengakibatkan bertambahnya beban keluarga, beban masyarakat dan tentu saja akan menjadi beban pemerintah baik di pusat maupun didaerah sehingga saat Himpunan Lansia Sayang Bunda Sulawesi Selatan bersama pemerintah danmasyarakat serta seluruh elemen bahu membahu dalam uapay menjaga dan meningkatkan kesejahteraan lansia.

Dipahami bahwa eksistensi Himpunan Lansia Sayang Bunda Sulawesi Selatan, menjadi bagian yang tidak terpisahkan dari proses pembangunan di Sulawesi Selatan yang merupakan provinsi terbaik dengan pertumbuhan ekonomi tertinggi secara nasional. Selain itu, Sulawesi Selatan juga merupakan pilar utama nasional serta pusat simpul jejaring dalam peningkatan tingkat kesejahteraan Lansia.

Berbagai pernyataan yang menegaskan bahwa Himpunan Lansia Sayang Bunda Sulawesi Selatan, sangat dibutuhkan eksistensinya. Ini bukti sejak organisasi tersebut didirikan oleh pendirinya, $\mathrm{Hj}$. Ince Ratna Nurhayati Yasin Limpo telah melaksanakan berbagai kegiatan. Dinyatakan oleh $\mathrm{Hj}$. Andi Rasdianah amir bahwa,

Dalam sosial kemasyarakatan mampu memberikan motivasi dan menggerakkan kaum ibu-ibu Aisyiah dan ibu-ibu lainnya dalam membantu sesama perempuan untuk mengembangkan dirinya dalam berbagai aktivitas. Bahkan oleh beliau ( $\mathrm{Hj}$. Ince Ratna Nurhayati Yasin Limpo [pen]) mampu memberi motivasi kepada ibu-ibu lansia untuk tidak menjadi beban di keluarga, tetapi menjadi inspirasi bagi keluarga dalam mencapai keberhasilan di tengah-tengah masyarakat.

Dalam membela hak-hak pernah beliau (Hj. Ince Ratna Nurhayati Yasin Limpo [pen]) berjuang untuk memperjuangkan keterwakilan perempuan di berbagai aktivitas, terutama keterwakilan dalam legislative dan eksekutif. Dalam bidang kesejahteraan rakyat memberikan andil utama dalam membela hak-hak rakyat kecil seperti masyarakat tani dan nelayan, sehingga dalam pengambilan keputusan tentang holtikulturan beliau ( $\mathrm{Hj}$. Ince Ratna Nurhayati Yasin Limpo [pen]) banyak memberi sumbangan pemikiran. 


\section{SIMPULAN}

Eksistensi Himpunan Lansia Sayang Bunda di Sulawesi Selatan merupakan organisasi yang dibutuhkan masyarakat secara umum dan lansia pada khususnya. Kebutuhan tersebut seiring dengan berbagai manfaat yang telah dilakukan seperti ceramah agama, baksos, pelatihan ESQ, pelatihan kewirausanaan, pelatihan tenaga kerja, penghijauan yang dilaksanakan atas inisiatif pengurus dan bekerjasama dengan berbagai elemen, baik organisasi maupun pemerintah. Himpunan Lansia Sayang Bunda di Sulawesi Selatan berkomitmen untuk mengimplemetasikan pemberdayaan Lansia melalui berbagai kegiatan dakwah bil alHaal yang mengedepankan partisipatoris dan nafsiah, sehingga terjadi pemerataan perhatian kepada seluruh elemen lansia di Sulawesi Selatan.

\section{Endnote}

${ }^{1}$ Jumlah lanju tusia (Lansia) pada tahun 2014 di Indonesia sebesar 28, 68\% meningkat jauh dari tahun 2000 dengan persentase 7,74\%. (sumber data: Gambaran kesehatan lanjutusia di Indonesia (Pusat Data dan Informasi Kementrian Kesehatan RI).

${ }^{2}$ Undang-undang Republik Indonesia Nomor 13 tahun 1998 Tentang Kesejahteraan Lanjut Usia.

${ }^{3}$ Undang-undang Republik Indonesia nomor 13 tahun1998 tentang kesejahteraan LanjutUsia.

${ }^{4}$ Pudjiastuti, S.S dan Utomo, B., Fisioterapi pada Lansia(Jakarta: EGC, 2002), h. 48-49.

163.

${ }^{5}$ Siti Partini Suardiman, Psikologi Usia Lanjut (Yogyakarta: Gajah Mada University Press, 2012), h. Sosiologis, h. 32.

${ }^{7}$ Siti Partini Suardiman, Psikologi Usia lanjut, h. 101.

${ }^{8}$ Pudjiastuti, S.S., dan Utomo, B., Fisioterapi pada Lansia,76-77.

${ }^{9}$ Baca Morrisan, Teori Komunikasi Individu Hingga Massa (Jakarta: Graha, 2009), h. 391.

${ }^{10} \mathrm{Hj}$. Ince Ratna Nurhayati YasinLimpo, dalam "Riwayat Lansia Sayang Bunda Sulawesi Selatan", tahun 2013 , h. 1 .

${ }^{11}$ Hj. Ince Ratna Nurhayati Yasin Limpo (79 tahun), Pendiri dan KetuaHimpunanLansia Sayang Bunda Sulawesi Selatan, Wawancaraoleh penulis di kota Makassar, tanggal 5 juli 2014.

${ }^{12} \mathrm{Hj}$. Ince Ratna Nurhayati YasinLimpo (79 tahun), Pendiri dan Ketua Himpunan Lansia Sayang Bunda Sulawesi Selatan, Wawancara oleh penulis di kota Makassar, tanggal 5 juli 2014.

${ }^{13} \mathrm{Hj}$. Ince Ratna Nurhayati Yasin Limpo (79 tahun), Pendiri dan Ketua Himpunan Lansia Sayang BundaSulawesi Selatan, Wawancara oleh Penulis di Kota Makassar, tanggal 7 juli 2014.

${ }^{14} \mathrm{Hj}$. Hadijah Usman (62 tahun), Sekretaris Himpunan Lansia Sayang Bunda Sulawesi Selatan, Wawancara oleh Penulis di Kota Makassar, tanggal 9 Agustus 2014.

${ }^{15}$ Badan Pusat Statistik Provinsi Sulawesi Selatan dalam "Laporan Tahunan 2014" (Makassar: Bidang Registrasi Penduduk, 2014), h. 2.

\section{DAFTAR PUSTAKA}


Morrisan, Teori Komunikasi Individu Hingga Massa (Jakarta: Graha, 2009)

Badan Pusat Statistik Provinsi Sulawesi Selatan dalam "LaporanTahunan 2014" (Makassar: Bidang Registrasi Penduduk, 2014)

Preyitno, "Memahami KepribadianLansia" dalamAryo(ed), Problematika Lansia dalam Tinjauan Sosiologis,

Pudjiastuti, S.S., danUtomo, B., FisioterapipadaLansia,Jakarta: EGC, 2002.

Siti Partini Suardiman, Psikologi Usia Lanjut, Yogyakarta: Gajah Mada University Press, 2012.

Undang-undang Republik Indonesia Nomor 13 tahun 1998 Tentang Kesejahteraan Lanjut Usia. 